\title{
The Effectiveness of Binahong (Anredera cordifolia (Ten.) Steenis) Extract in Promoting Fertility in Male Wistar Rats after Exposure to Cigarette Smoke
}

\author{
Achmad Ramadhan* \\ Study Program of Biology Education, Faculty of Teacher Training and Education, Tadulako University, City of Palu, Indonesia
}

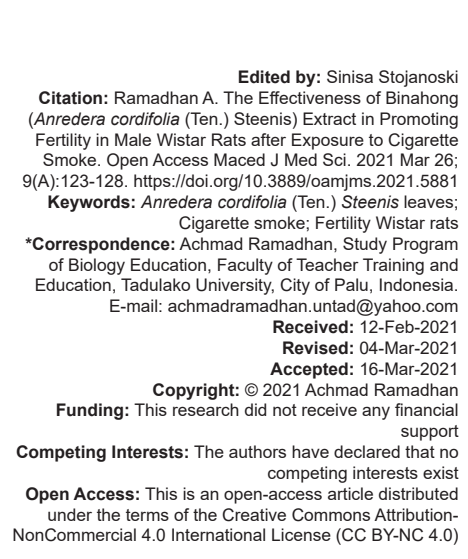

\section{Introduction}

Cigarette smoke is a source of free radicals. Free radicals are generated due to incomplete combustion [1]. Cigarette exposure can result in cardiomyopathy and an immune reaction in the liver [2]. Epidemiological studies reveal that exposure to Second Hand Smoke leads to an increased risk of lung cancer by $20-30 \%$, heart disease by $25-30 \%$, stroke by up to $82 \%$, and an increased risk of other non-fatal respiratory diseases [3]. Cigarettes can also affect the decrease in serum antioxidants, which triggers oxidative stress, DNA damage, and cell apoptosis [4]. As an air pollutant, unfiltered tobacco smoke contains 3 times more nicotine. Apart from nicotine, tobacco smoke contains more than 4000 types of constituents, including tar, carbonate monoxide, polycyclic aromatic hydrocarbons, heavy metals, and other pyrolysis derivatives [5], [6].

Several reproduction studies report that smoking can cause decreased semen quality, reproductive system dysfunction, hormone disturbances, spermatogenesis, sperm maturation, and spermatozoa function [5], [7], [8]. The mechanism of decreased sperm function under oxidative stress has been shown to involve excessive reactive oxygen species (ROS). To counteract the effects of ROS, spermatozoa and seminal plasma have many antioxidant systems. Spermatozoa have a low number of cellular ROS defense systems consisting of catalase, superoxide dismutase, glutathione peroxidase, and Vitamin E. Similarly, seminal plasma has an antioxidant buffer capacity [9]. However, other studies have also revealed that infertile men have a low seminal plasma non-enzymatic antioxidant capacity, so the likelihood of being exposed to ROS is very high [10].

Several studies have reported that antioxidants and Vitamins $A, B, C$, and $E$ in food can protect sperm DNA from free radicals and increase blood-barrier-testis stability and can improve sperm quality and improve fertility sperm quality rates in men [11], [12]. Many plant-derived substances, called phytonutrients, or phytochemicals, are becoming recognized for their antioxidant activity. About 3000 flavonoids from phenol derivatives found in plants 
are known [13]. It is known that one of the plants that have active compounds is binahong (Anredera cordifolia (Ten.).

The binahong plant ( $A$. cordifolia) is a plant from the Basellaceae family. This plant is known as Madeira vine or Mignonette vine, in Indonesia, it is known as binahong. This plant can grow in tropical, subtropical, and Mediterranean areas. This plant is often used by the community as a traditional medicine for various diseases. This plant contains flavonoids, alkaloids, triterpenoids, saponins, and essential oils and Vitamin C. Binahong leaves also contain phytoestrogens, which work as estrogens that can affect the production and breakdown of the hormone estrogen by the body. Therefore, nutritional factors in reproductive and fertility care are critical.

This study was conducted to assess the ability of binahong leaf extract ( $A$. cordifolia (Ten.) to increase fertility parameters of male Wistar rats after exposure to cigarette smoke.

\section{Methods}

\section{Experimental animals}

The experimental animals used were 24 male Wistar rats preserved in the Biology Laboratory of Faculty of Teacher Training and Education (FKIP), Tadulako University. The maintenance room was illuminated for $12 \mathrm{~h}$ (06.00-18.00). The experimental rats fed with domestic chicken feed granules produced by PT Charoen Pokphand Indonesia (protein value 14-16) and given ad libitum drinking water. The rats used were aged 3 months old, with an average initial body weight of 150 $200 \mathrm{~g}$. The experimental animals were divided into six groups, each group consisting of four rats (replication).

\section{Research design}

The research was conducted in November 2018 at the Biology Education Laboratory, Faculty of Teacher Training and Education (FKIP), Tadulako University. The research design used a laboratory experiment with a completely randomized design, six treatments, and four replications. The treatment groups were detailed as follows:

Group 1 = Standard control (without smoke exposure and extracts treatment)

Group 2 = Negative control, exposed to cigarette smoke without extract.

Group 3 = Exposed by cigarette smoke and had extract at a dose of $25 \mathrm{mg} / \mathrm{kg}$ body weight

Group 4 = Exposed by cigarette smoke and had extract at a dose of $50 \mathrm{mg} / \mathrm{kg}$ body weight

Group 5 = Exposed by cigarette smoke and had extract at a dose of $75 \mathrm{mg} / \mathrm{kg}$ body weight

Group $6=$ Exposed by cigarette smoke and had extract at a dose of $100 \mathrm{mg} / \mathrm{kg}$ body weight

\section{Research procedure}

\section{Binahong leaf extract preparation}

Binahong leaf extract was prepared initially by 10 days air-dried of $250 \mathrm{~g}$ of binahong leaves. The dried leaves then ground and made into simplicia. The simplicia was immersed in $500 \mathrm{ml}$ of methanol for 48-72 $\mathrm{h}$ and filtered using a Buechner funnel and concentrated using a rotary evaporator.

\section{Exposure to cigarette smoke and intervention} of binahong leaf extract

Smoke exposure to Wistar rats was conducted in a smoking chamber, a vacuum desiccator equipped with an open tube [14]. The cigarette was positioned at one end. The tube was connected to the vacuum with a stopcock placed at the top. Rats were placed in the smoking chamber, and cigarettes were lit. Puffs of smoke were drawn into the room using an air straw for $20 \mathrm{~s}$. The rats were exposed to the accumulated smoke for $40 \mathrm{~s}$. After that, the room was ventilated for $1 \mathrm{~min}$ with fresh air. Exposure of cigarette smoke to experimental animals was carried out for 14 days. On day 15, the experimental animals had binahong leaf extract for about 48 days, about $0.5 \mathrm{ml}$ extract/day for each.

\section{Assessment of Wistar male rats fertility profile}

The fertility profile of rats after being exposed to cigarette smoke and given binahong leaf extract was assessed by measuring the response: (1) Body weight, (2) genital weight (testes, epididymis), and (3) spermogram. Measurements of the observed spermogram response included velocity, motility, morphology, and number of spermatozoa.

\section{Data analysis}

Statistical analysis of the data was performed using Univariate analysis/analysis of variance (ANOVA). $F$ value or $p<0.05$ was considered significant. Ethical committee approval with number: 9681A/UN28.1.31/ PT/2020 by Animal Ethics Commission for Animal Research, Faculty of Animal Husbandry and Fisheries, Tadulako University, June 20, 2020

\section{Results}

The response of body weight and weight gain rate of male Wistar rats

The observation results on the effectiveness of binahong extract on the response to body weight and the rate of weight gain of rats after being exposed to cigarette smoke are presented in Table 1. 
Table 1: The body weight and weight gain rate of male Wistar rats exposed to cigarette smoke and given binahong leaf extract

\begin{tabular}{lccc}
\hline $\begin{array}{l}\text { Intervention } \\
\text { groups }\end{array}$ & \multicolumn{2}{l}{ Average body weight (g } & \multirow{2}{*}{$\begin{array}{l}\text { Average weight } \\
\text { gain rate }(\mathrm{g} / \text { day) }\end{array}$} \\
\cline { 2 - 3 } $\begin{array}{l}\text { Before } \\
\text { (day 0) }\end{array}$ & $\begin{array}{c}\text { Average Weight } \\
\text { Gain Rate (g/day) }\end{array}$ & \\
\hline $\begin{array}{l}\text { Group 1 } \\
\text { (control normal) }\end{array}$ & 151.05 & 216.97 & $1.37^{\mathrm{a}}$ \\
$\begin{array}{l}\text { Group 2 } \\
\text { (control negative) }\end{array}$ & 150.12 & 211.87 & $1.28^{\mathrm{a}}$ \\
Group 3 & 151.47 & 213,00 & $1.28^{\mathrm{a}}$ \\
Group 4 & 152.12 & 213.35 & $1.27^{\mathrm{a}}$ \\
Group 5 & 150.12 & 215.55 & $1.36^{\mathrm{a}}$ \\
Group 6 & 152.20 & 215.42 & $1.31^{\mathrm{a}}$ \\
\hline LSD test results at the 95\% confidence level $(\mathrm{p}<0.05)$. The same letter in one column between treatments
\end{tabular}

LSD

Based on the results of the least significance different (LSD) test, it was found that there was no significant difference in the weight gain rate of rats between treatments and with standard control and negative control.

\section{Weight of Wistar male rats reproductive organs}

The ANOVA showed that binahong leaf extract had a significant effect on rats' testicular weight, but had no significant effect on epididymal weight. The average weight of the reproductive organs based on the LSD test is shown in Table 2.

In Table 2, the average testicular weight of rats exposed to cigarette smoke for 14 days was significantly different from standard control treatment or with doses of 50,75 , and $100 \mathrm{mg} / \mathrm{kg}$ body weight, but at a dose of $25 \mathrm{mg} / \mathrm{kg}$ body weight (Group 4) has not shown a significant increase when compared to control (Group 1).

\section{Male Wistar rat spermatozoa spermiogram}

The ANOVA showed that the binahong leaf extract had a significant effect on the spermatozoa spermogram of rats. The data from the calculation results and the LSD test for each spermogram response are shown in Table 3.

From Table 3, it is clear that the negative control (Group 2) and the treatment dose of $25 \mathrm{mg} / \mathrm{kg}$ body weight, spermatozoa velocity until day 48 had not seen a significant increase when compared with normal controls. The average velocity reached $12.43 \mathrm{~mm}^{2} / \mathrm{s}$ and $13.36 \mathrm{~mm}^{2} / \mathrm{s}$. The spermatozoa velocity increased significantly at Group 6 (dosage 100 mg/kg body weight).

The percentage of motile sperm in an experimental animal exposed to cigarette smoke for 14 days without extract (Group 1) decreased significantly. The mean decrease in motility when compared with normal controls was $26 \%$. The percentage of motile sperm between doses of 25,50 , and $75 \mathrm{mg} / \mathrm{kg}$ body weight showed an increase with increasing doses given. However, only a dose of $100 \mathrm{mg} / \mathrm{kg}$ body weight showed a significant difference (Table 3).

Observations on sperm morphology indicated that sperm morphology abnormalities caused by exposure to cigarette smoke were mainly in the form of separate sperm with a head and tail or a broken tail. The percentage of broken sperm between negative controls with doses of $25,50,75$, and $100 \mathrm{mg} / \mathrm{kg}$ body weight showed a significant difference. However, with binahong leaf extract administration, the tendency to improve sperm morphology was seen, especially at the dose of $100 \mathrm{mg} / \mathrm{kg}$ body weight (Table 3).

The mean sperm count of rats exposed to cigarette smoke for 14 days decreased compared to normal controls (Group 1). Likewise, at doses of 25 , 50 , and $75 \mathrm{mg} / \mathrm{kg}$ body weight, there was a decrease in the number of spermatozoa. Although the binahong leaf extract was given for 48 days, the sperm count statistically did not show a significant increase when compared to normal controls. The increase in sperm occurred significantly at a dose of $100 \mathrm{mg} / \mathrm{kg}$ body weight (Table 3).

\section{Discussion}

\section{White rat (Rattus norvegicus) fertility profile}

The body weight measurement showed that cigarette smoke-exposed to male rats did not cause

Table 2: Weight of male Wistar rats' reproductive organs exposed to cigarette smoke for 14 days and intervened with binahong leaf extract

\begin{tabular}{|c|c|c|c|c|c|c|c|}
\hline \multirow[t]{2}{*}{ Reproductive organs } & \multirow[t]{2}{*}{ Duration of treatment (Day) } & \multicolumn{6}{|c|}{ Average organ weight (mg/100 $\mathrm{g}$ body weight) } \\
\hline & & Group 1 & Group 2 & Group 3 & Group 4 & Group 5 & Group 6 \\
\hline Testicles & 48 & $305.75^{\mathrm{a}}$ & $291.00^{b}$ & $297.50^{\mathrm{b}}$ & $303.00^{\mathrm{a}}$ & $301.25^{\mathrm{a}}$ & $303.50^{\mathrm{a}}$ \\
\hline Epididymis & 48 & $122.00^{\mathrm{a}}$ & $114.50^{\mathrm{a}}$ & $118.75^{\mathrm{a}}$ & $117.75^{\mathrm{a}}$ & $118.50^{\mathrm{a}}$ & $119.25^{\mathrm{a}}$ \\
\hline
\end{tabular}

Table 3: Spermatozoa spermogram after exposure to cigarette smoke for 14 days and given Binahong leaf extract for 48 days

\begin{tabular}{|c|c|c|c|c|}
\hline Dosage $(\mathrm{mg} / \mathrm{kg} \mathrm{BW})$ & Spermatozoa velocity $(0.2 \mathrm{~mm} 2 / \mathrm{XS})(\mathrm{X} \pm \mathrm{SD})$ & Motility $(\%)(X \pm S D)$ & $\sum$ sperm morphology abnormalities $(\mathrm{X} \pm \mathrm{SD})$ & Sperm count $(106 / \mathrm{ml})(\mathrm{X} \pm \mathrm{SD})$ \\
\hline Group 1 (control normal) & $39.07^{\mathrm{a}} \pm 1.37$ & $82^{\mathrm{a}} \pm 4.95$ & $10^{\mathrm{a}} \pm 2.22$ & $4.05^{\mathrm{a}} \pm 0.37$ \\
\hline Group 2 (control negative) & $12.43^{b} \pm 1.92$ & $56^{b} \pm 7.18$ & $34^{b} \pm 2.75$ & $3.07^{b} \pm 0.61$ \\
\hline Group 3 & $13.36^{\mathrm{b}} \pm 1.35$ & $59^{b} \pm 3.64$ & $30^{c} \pm 2.22$ & $2.87^{\mathrm{b}} \pm 0.46$ \\
\hline Group 4 & $16.33^{\mathrm{c}} \pm 1.33$ & $61^{b} \pm 3.00$ & $28^{\mathrm{d}} \pm 2.22$ & $3.45^{\mathrm{b}} \pm 0.39$ \\
\hline Group 5 & $26.67^{\mathrm{d}} \pm 1.35$ & $67^{\mathrm{b}} \pm 2.12$ & $22^{\mathrm{e}} \pm 2.22$ & $3.65^{b} \pm 0.13$ \\
\hline Group 6 & $38.47^{\mathrm{a}} \pm 3.17$ & $80^{\mathrm{a}} \pm 1.41$ & $17^{f} \pm 2.94$ & $3.95^{\mathrm{ab}} \pm 0.37$ \\
\hline
\end{tabular}


weight loss, as did the treatment given binahong leaf extract. It indicates that the rats exposed to cigarette smoke for 14 days and given binahong leaf extract for 48 days did not interfere with the rats' eating activities so that their body weight did not decrease. The lowest average weight gain rate was $1.27 \mathrm{~g} /$ day, and the highest was $1.37 \mathrm{~g} /$ day. Based on the weight gain rate data, it can be assumed that cigarette smoke and binahong leaf extract do not interfere with the transit time of food in the intestine and the absorption of food substances to increase the rats' weight. It also shows that giving cigarette smoke for 14 days has not caused a toxic effect on experimental animals (negative control). Likewise, binahong leaf extract given for 48 days at doses of 25, 50, 75 , and $100 \mathrm{mg} / \mathrm{kg}$ body weight has not been able to cause toxic effects in mice. An active substance's effectiveness is strongly influenced by the administration's dose and duration [15]. Symptoms of toxicity can be caused by the accumulation of active substances in the animal's body due to the low elimination rate.

The results of measuring the reproductive organs' weight showed that the treated rats' testicular weight exposed to cigarette smoke decreased significantly. In treatment 1 (rats exposed and given binahong leaf extract at a dose of $25 \mathrm{mg} / \mathrm{kg}$ body weight) did not show any increase in testicular weight. However, in Group 4, Group 5, and Group 6 treatments, there was a significant increase in testicular weight. The decrease in testicular weight in rats exposed to cigarette smoke was probably due to decreased spermatids 19 and spermatids 7, thus causing the testes to be slightly smaller. However, this still needs further research. The epididymis reproductive organs' weight did not significantly affect weight reduction compared to controls or between treatments. If there is a decrease in epididymal weight, this indicates a disturbance in the epididymis' development and function. It is caused by decreased testosterone levels produced by Leydig cells, causing changes in the epididymal duct. However, it is not yet certain whether cigarette smoke affects the epididymis' histological structure, still needs to be further proven.

\section{White rat ( $R$. norvegicus) spermatozoa spermiogram}

The results showed that cigarette smoke caused a significant decrease in sperm quality. The decrease in spermatozoa function (speed, motility, morphology, and quantity) is due to cigarette smoke containing nicotine and carcinogenic substances [16]. The findings in this study are supported by research conducted by Aryanpur et al. that cigarette smoke can directly or indirectly cause interference with spermatogenesis. The main content possessed by cigarettes is nicotine [17]. The decrease in spermatozoa's speed exposed to cigarette smoke in the negative control was due to cigarette smoke containing nicotine and carcinogenic substances. Apart from nicotine, tobacco smoke contains more than 4000 types of constituents, including tar, carbonate monoxide, polycyclic aromatic hydrocarbons, heavy metals, and other pyrolysis derivatives [18]. Cigarette smoke is a source of free radicals [19]. Free radicals are generated due to incomplete combustion [1]. The mechanism of decreased sperm function under oxidative stress has been shown to involve excessive ROS [20]. Various cigarette smoke components can cross the blood-testis barrier, causing significant changes in sperm quality, such as decreased sperm concentration, morphology, and motility of spermatozoa [21]. Although not very clear, proposed mechanisms for cigarette smoke effects on reproductive function include increased oxidative stress and DNA damage. Smoking is the primary exogenous source of ROS capable of inducing lipid peroxidation, DNA damage, and apoptosis of sperm cells [22]. Other studies have also shown that smoking can reduce spermatogenesis, and the number of mature sperm cells produced and reduce fertile quality and capacity [23].

Giving binahong leaf extract can increase the speed of spermatozoa, this is because binahong leaves contain various antioxidant agents, such as natural polyphenol products containing endogenous antioxidants, can capture free radicals and oxidants, and regulate redox gene expression and glutathione biosynthesis genes, chromatin remodeling, and inflammatory gene expression. Spermatozoa motility in rats exposed to cigarette smoke decreased significantly with an average motility percentage of $56 \%$. The increase in spermatozoa motility occurred after administering binahong leaf extract at a dose of $100 \mathrm{mg} / \mathrm{kg}$ body weight. The administration of binahong leaf extract at a dose of $25 \mathrm{mg} / \mathrm{kg}$ body weight to $75 \mathrm{mg} / \mathrm{kg}$ body weight has not significantly increased spermatozoa motility. The decrease in spermatozoa motility is thought to be caused by cigarette smoke, affecting the epididymis structure, namely, the degeneration of the epididymis's epithelial ductal head cauda epididymis. Epithelial degeneration of the epididymis disrupts epididymal function, namely, reabsorption and secretion. It is suspected that a change in the fluid content in the lumen of the epididymis, which ultimately disrupts the spermatozoa spermogram. Epididymis provides a specific chemical environment for spermatozoa maturation. One of the epididymal lumen fluid characteristics is several particular proteins that can interact with spermatozoa membrane proteins. Along the epididymal duct, there is a process of addition or reduction of epididymal fluid protein.

Abnormal spermatozoa have head and tail defects [24]. Besides, the possibility of abnormal spermatozoa occurs when spermatozoa are released from the Sertoli cells in the seminiferous tubules [25]. Another possibility is that the spermatozoa's morphological abnormality is caused by disruption of the spermatozoa membrane's permeability [22]. It is suspected that cigarette smoke can cause cell shrinkage to interfere with integrating proteins and lipid bilayers on the membrane. Thus, the 
membrane permeability decreases; thus, sodium and potassium transport involving $\mathrm{Na}+, \mathrm{K}+$, and ATPase are disrupted. It will cause fluid to enter the cell in large enough numbers to experience edema. In the observation, several spermatozoa with large heads (macrocephalus) were found, which is thought to be due to the influx of large amounts of fluid. $\mathrm{Na}$ ,$+ \mathrm{K}+$, and ATPase are integral membrane proteins that function to maintain and maintain a balance of sodium and potassium transportation into cells. The administration of binahong leaf extract at a dose of 100 $\mathrm{mg} / \mathrm{kg}$ body weight can increase normal spermatozoa in rat epididymis cauda. This increase is thought to be related to the active compounds found in binahong leaves which can cause an increase in the number of normal spermatozoa forms. A decrease in spermatozoa occurred in mice exposed to cigarette smoke and not given binahong leaf extract. In mice given binahong leaf extract, there was an increase in the number of white rats' spermatozoa. The increase in number starts at a dose of 50,75 , and 100 of body weight. The increasing concentration (number) of spermatozoa in cauda epididymis is thought to be binahong leaves with moderate to high doses can increase the secretion of proteins, carbohydrates, lipids, and other specific components required for the physiological maturation process of spermatozoa in the epididymis. As it is known, there are many active sites of androgens on the head of the epididymis, which stimulate the synthesis of various peptides. These peptides will be secreted into the epididymis lumen, and there will be incorporated into the surface layer of spermatozoa. However, this still needs further investigation.

\section{Conclusions}

A. cordifolia leaf extract at a dose of $100 \mathrm{mg} / \mathrm{kg}$ body weight was effective in increasing the fertility of male Wistar rats exposed to cigarette smoke.

\section{Acknowledgment}

The authors thank to his Students for Supporting this Research.

\section{References}

1. Baker RR. Smoke generation inside a burning cigarette: Modifying combustion to develop cigarettes that may be less hazardous to health. In: Progress in Energy and Combustion Science. Vol. 32. ???: ???; 2005. p. 373-85. https://doi. org/10.1016/j.pecs.2006.01.001

2. Leone AL Jr., Biadi O, Balbarini A. Smoking and cardiovascular system: Cellular features of the damage. Curr Pharm Des. 2008;14:1771-7. https://doi.org/10.2174/138161208784746699 PMid: 18673180

3. Lim KH, Teh $\mathrm{CH}$, Mohamed MH, Pan S, Ling MY, Yusoff MF, et al Exposure to tobacco secondhand smoke and its associated factors among non-smoking adults in smoking-restricted and non-restricted areas: Findings from a nationwide study in Malaysia. BMJ Open 2018;8:e017203. https://doi.org/10.1136/ bmjopen-2017-017203

4. Knight-Lozano CA, Young CG, Burow DL, Hu ZY, Uyeminami S Pinkerton KE, et al. Cigarette smoke exposure and hypercholesterolemia increase mitochondrial damage in cardiovascular tissues. Circulation. 2015;105:849-54. https:// doi.org/10.1161/hc0702.103977

5. Condorelli RA, La VigneraS, Giacone F, lacoviello L, Vicari E, Mongioi $L$, et al. In vitro effects of nicotine on sperm motility and bio-functional flow cytometry sperm parameters. Int $\mathrm{J}$ Immunopathol Pharmacol. 2013;26(3):739-46. https://doi. org/10.1177/039463201302600317

PMid:24067470

6. Jeng HA, Chen Y, Kantaria KN. Association of cigarette smoking with reproductive hormone levels and semen quality in healthy adult men in Taiwan Association of cigarette smoking with. $J$ Environ Sci Health Part A. 2014;49:37-41. https://doi.org/10.108 0/10934529.2014.846195

PMid:24279617

7. Perrin J, Tassistro V, Mandon M. Tobacco consumption and benzo ( a ) pyrene-diol- epoxide-DNA adducts in spermatozoa: In smokers, swim-up procedure selects spermatozoa with decreased DNA damage. Fertil Steril. 2013;95(6):2013-7. https://doi.org/10.1016/j.fertnstert.2011.02.021

PMid:21406302

8. Kovac JR, Khanna A, Lipshultz LI, The effects of cigarette smoking on male fertility. Postgrad Med. 2015;127(3):338-41. http://doi.org/10.1080/00325481.2015.1015928

PMid:25697426.

9. Sheweita SA, Tilmisany AM, Al-Sawaf H. Mechanisms of male infertility: Role of antioxidants. Curr Drug Metab. 2005;6:495501. https://doi.org/10.2174/138920005774330594 PMid: 16248841

10. Sabeti P, Pourmasumi S, Rahiminia T, Akyash F, Talebi AR. Etiologies of sperm oxidative stress. Int $\mathrm{J}$ Reprod Biomed. 2016;14(4):231-40. PMid:27351024

11. Tremellen K. Oxidative stress and male infertility a clinica perspective. Hum Reprod Update. 2008;14(3):243-58. https:// doi.org/10.1093/humupd/dmn004

PMid:18281241

12. Ahmadi S, Bashiri R, Ghadiri-Anari A, Nadjarzadeh A Antioxidant supplements and semen parameters: An evidence based review. Int J Reprod Biomed. 2016;14(12):729-36. PMid:28066832

13. Hatch E. Asthma, inhaled oxidants, and dietary antioxidants. Am J Clin Nutr. 1995;61:625S-30. https://doi.org/10.1093/ ajcn/61.3.625s PMid:7879729

14. Ahmadnia $H$, Ghanbari M, Moradi MR, Khaje-Dalouee M Effect of cigarette smoke on spermatogenesis in rats. Urol J. 2007;4(3):159-63.

PMid: 17987579

15. Turner PV, Brabb T, Pekow C, Vasbinder MA. Administration of 
substances to laboratory animals: routes of administration and factors to consider. J Am Assoc Lab Anim Sci. 2011;50(5):600-13. PMid:22330705

16. Ribeiro LI, Ind PW. Effect of cannabis smoking on lung function and respiratory symptoms: A structured literature review. NPJ Prim Care Respir Med. 2016;26:16071. https://doi.org/10.1038/ npjpcrm.2016.71

PMid:27763599

17. Aryanpur M, Tarahomi M, Sharifi H, Heydari G, Hessami Z, Akhoundi $\mathrm{M}$, et al. Comparison of spermatozoa quality in male smokers and nonsmokers of Iranian infertile couples. Int J Ferti Steril. 2011;5(3):152-7.

PMid:25101159

18. Dai JB, Wang ZX, Qiao ZD. The hazardous effects of tobacco smoking on male fertility. Asian J Androl. 2015;17(6):954-60. https://doi.org/10.4103/1008-682x.150847

PMid:25851659

19. Church DF, Pryor WA. Free-radical chemistry of cigarette smoke and its toxicological implications. Environ Health Perspect. 1985;64:111-26. https://doi.org/10.1289/ehp.8564111 PMid:3007083

20. Bansal AK, Bilaspuri GS. Impacts of oxidative stress and antioxidants on semen functions. Vet Med Int. 2010;2010:686137.
PMid:20871827

21. Rehman R, Zahid N, Amjad S, Baig M, Gazzaz ZJ. Relationship between smoking habit and sperm parameters among patients attending an infertility clinic. Front Physiol. 2019;10:1356. https://doi.org/10.3389/fphys.2019.01356

PMid:31736779

22. Dutta S, Majzoub A, Agarwal A. Oxidative stress and sperm function: A systematic review on evaluation and management. Arab J Urol. 2019;17(2):87-97. https://doi.org/10.1080/20905 98x.2019.1599624

PMid:31285919

23. Sansone A, Dato CD, de Angelis C, Menafra D, Pozza C Pivonello R. Smoke, alcohol and drug addiction and male fertility. Reprod Biol Endocrinol. 2018;16:3. https://doi.org/10.1186/ s12958-018-0320-7 PMid:29334961

24. Rondanino $\mathrm{C}$, et al. Evaluation of sperm nuclear integrity in patients with different percentages of decapitated sperm in ejaculates. Reprod Biomed Online. 2015;31(1):89-99. https:// doi.org/10.1016/j.rbmo.2015.04.002

PMid:26001636

25. Suede SH, Malik A, Sapra A. Histology, Spermatogenesis. Treasure Island, FL: StatPearls Publishing; 2020. 